\author{
Нікішина О.В. \\ доктор економічних наук, старший науковий співробітник \\ відділ ринкових механізмів та структур \\ Інститут проблем ринку та економіко-екологічних досліджень НАН України \\ Французький бульвар, 29, м. Одеса, Україна, 65044 \\ E-mail: ksenkych@gmail.com
}

\title{
ВІДТВОРЮВАЛЬНИЙ МЕТОДИЧНИЙ ПІДХІД ДО ОЦІНКИ ЕФЕКТИВНОСТІ ІНТЕГРОВАНИХ ТОВАРНИХ РИНКІВ
}

Досліджено природу доданої вартості у секторному та ринковому вимірі, розроблено теорію колообігу секторної доданої вартості в мезосистемі з акцентом на головні етапи її руху (процеси фрормування й використання), міжсекторний перерозподіл та протиріччя економічних інтересів учасників процесу відтворення. На основі даного теоретичного фундаменту розроблено відтворювальний методичний підхід до оцінки ефективності функціонування інтегрованих товарних ринків, що базується на трьохрівневій системі показників, вбудований у загальну методологію ринкового дослідження та взаємопов'язаний з процесами діагностики, прогнозування, управління й регулювання товарних ринків. Обґрунтовано напрями практичного впровадження авторського методичного підходу на мікро- та мезорівнях.

Ключові слова: додана вартість, мезосистема, ефективність інтегрованих товарних ринків, колообіг секторної доданої вартості, управління вартістю.

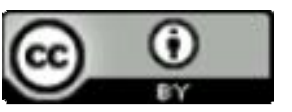

This work is licensed under a Creative Commons Attribution 4.0 International License http://creativecommons.org/licenses/by/4.0/

Постановка проблеми та її зв'язок з важливими науковими та практичними завданнями. В умовах глобалізації необхідною умовою сталого економічного зростання держави $є$ ефективне функціонування інтегрованих товарних ринків (далі ITP), у секторах яких відбувається процес формування доданої вартості (далі - ДВ), що є внутрішнім ресурсом розвитку країни. Обгрунтування напрямів та інструментів підвищення ефективності ITP як багаторівневої системи обумовлює необхідність розробки нових теоретико-методичних підходів до оцінки ефективності товарних ринків, а також доповнення й коригування існуючих підходів 3 урахуванням вимог динамічного зовнішнього середовища, постановки багатомірних завдань тощо.

Актуальність обраної теми обумовлена необхідністю розвитку відтворювального теоретикометодичного підходу до оцінки ефективності ITP, тому що це підгрунтя є основою для побудови механізму державного управління ДВ у стратегічних ринках країни.

Аналіз останніх публікацій по проблемі. Проблемі методичного забезпечення оцінки ефективності економічних систем різних рівнів присвячені наукові праці Авдашевої С.Б. [1], Булиги Р., Кохно П. [2], Грідчиної М. В. [3], Іваненко В. О. [4], Ізмайлової К. В. [5], Коваленка О. В. [6], Лисюка В.М. [7], Савицької Г. В. [8], Сінка Д. С. [9] та інших учених. Водночас недостатньо вивченим у теоретичноприкладній площині залишається питання оцінки ефективності ITP як багаторівневої мезоекономічної системи, взаємного проектування наукових підходів щодо його полівекторного дослідження.

Формулювання цілей дослідження. Мета статті - розробка теоретичного підгрунтя і відтворювального методичного підходу до оцінки ефективності функціонування ITP - окреслила низку завдань:

- визначення природи секторної й ринкової доданої вартості;

- розробка теоретичних положень колоообігу секторної доданої вартості в мезосистемі (інтегрованому товарному ринку);

- обгрунтування методологічного підходу у двоєдності концептуального та методичного базисів до оцінки ефективності ITP;

- розробка багаторівневої системи показників для оцінки ефективності формування й використання доданої вартості у мезосистемі;

- обгрунтування напрямів практичного використання відтворювального методичного підходу.

Виклад основних результатів та їх обгрунтування. В економічній теорії окремий науковий підхід до оцінки ДВ, що продукується мезосистемами, зокрема, товарними ринками, відсутній. Дана обставина обумовлює необхідність проведення нових досліджень, а також поєднання існуючих шляхом конвергенції методик, використовуваних для мікро- й макросистем. Відтак, теоретичний фундамент для конструювання відтворювального методичного підходу до оцінки ефективності ITP формують два підходи: статистичний (макрорівень) і бухгалтерський (мікрорівень). 
Особливістю бухгалтерського підходу є зв'язок новоствореної вартості з її матеріальним носієм, тобто конкретним товаром, що є невід'ємною складовою ідентифікації релевантного ринку за товарними межами. Інтерпретація сутності доданої вартості, що продукується системами, є багатовекторною. Так, сучасна енциклопедія трактує додану вартість як вартість проданого продукту за вирахуванням вартості матеріалів, придбаних і використаних для його виробництва. ДВ дорівнює виручці, що включає заробітну плату, орендну плату, ренту, банківський відсоток, прибуток й амортизацію; в багатьох розвинених країнах слугує основою для непрямого оподаткування [10].

Інший підхід до трактування сутності доданої вартості знаходимо в Економічному словнику: вартість, що створена в процесі виробництва на даному підприємстві і відображає його реальний внесок у створення вартості конкретного продукту, що випускається [11]. На наш погляд, саме цей підхід найглибше визначає природу ДВ, відтак, може бути використаним для її інтерпретації на мезорівні в секторному вимірі. Таким чином, секторна додана вартість - це вартість, створена в процесі виробництва (надання послуг) суб' єктами господарювання певного сектору (сировинного, виробничого, торгового), що відобра- жає реальний внесок даного сектору в формування вартості товару (послуги) на інтегрованому ринку. Ринкова додана вартість включатиме суму секторних ДВ; їх кількість залежить від специфіки процесу відтворення певного товару в географічних межах держави. Оцінка структури ринкової ДВ може здійснюватися як в ресурсному, так і секторному розрізі.

Відправним пунктом побудови відтворювального методичного підходу до оцінки ефективності ITP є дослідження колообігу секторної доданої варmості, (рис. 1). Колообіг ДВ можна розділити на два основні етапи або процеси: процес формування та процес використання новоствореної вартості. 3 огляду на соціально-економічні функції, додана вартість відображає ступінь реалізації економічних інтересів усіх учасників процесу відтворення, що дає змогу виявити та проаналізувати різні варіанти протиріч інтересів у внутрішньому та зовнішньому вимірі. Дана властивість показника ДВ має цінне практичне значення для побудови методичного підходу та пошуку засобів подолання конфліктів економічних інтересів, які, безумовно, впливають на траєкторію руху новоствореної вартості в мезосистемі. Розглянемо процеси формування та використання секторної ДВ більш детально.

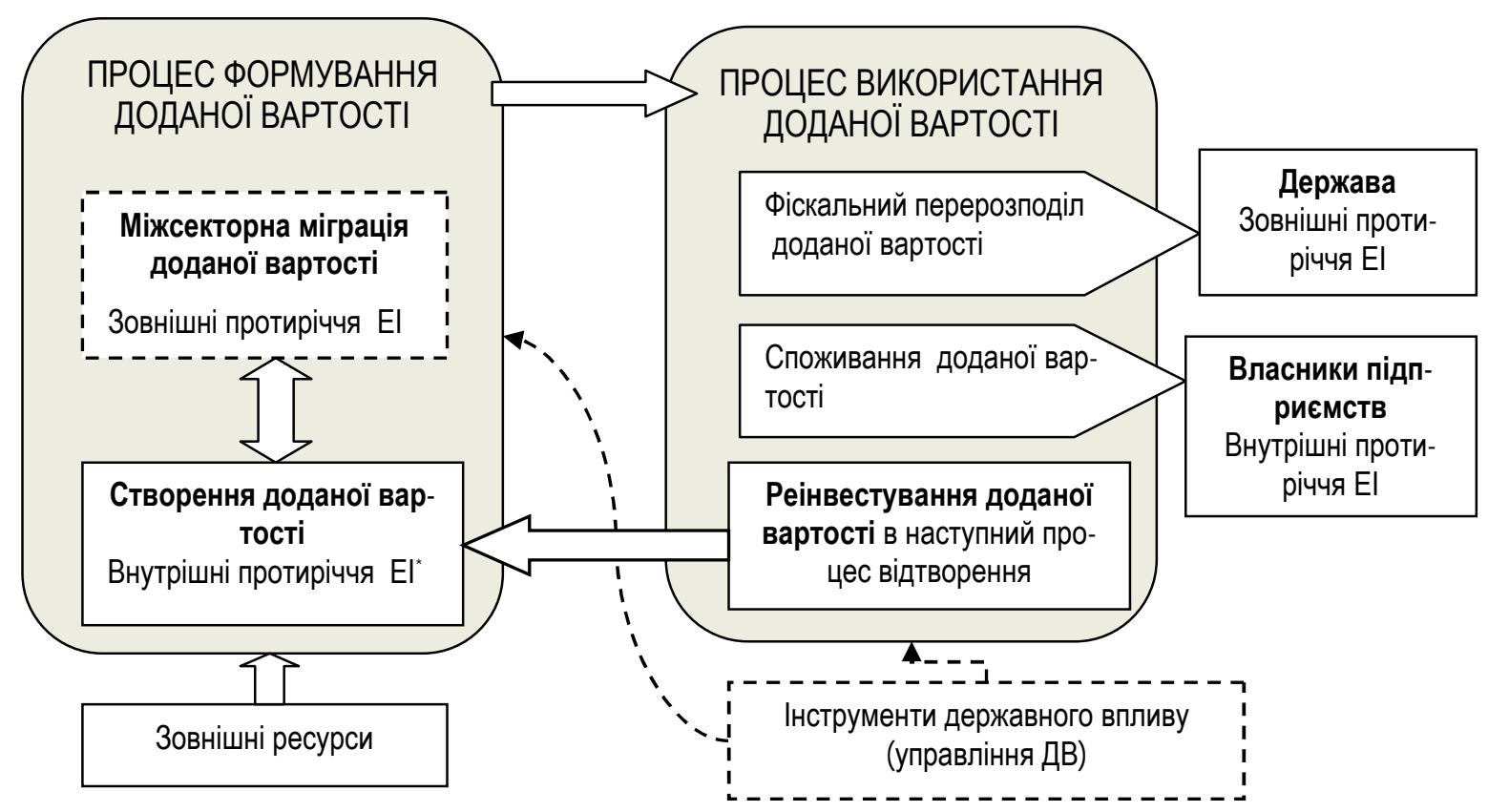

Умовні позначення: "ЕI - економічні інтереси.

Рис. 1. Колообіг секторної доданої вартості в інтегрованому товарному ринку* *авторська розробка

Додана вартість (ДВ виробництва товарів (надання послуг) суб'єктами господарювання, що розгортають свою діяльність у секторах ITP, та включає 4 компоненти: амортизацію необоротних активів (А), заробітну плату робітників (3П), прибуток (П) і специфічні витрати $\left(\mathrm{B}_{\mathrm{C}}\right)$ :

$$
2 \mathbf{B}_{\mathrm{C}}=\mathbf{A}+3 \Pi+\Pi+\mathbf{B}_{\mathrm{C}}
$$

Специфічні витрати відображають особливості процесів відтворення певних секторів ITP і притаманні лише їм. Наприклад, для ринків продукції рослинництва такими специфічними витратами є плата за оренду земельних паїв, для ринку насіння зернових культур - витрати на очищення й сортування насіння, і т.д. На 1 етапі колообігу формується структурна архітектура доданої вартості, й включення до її скла- 
ду специфічних витрат робить ії унікальною для кожного сектору досліджуваного ITP. У процесі формування секторної ДВ виникає внутрішне (секторне) протиріччя між інтересами працівників і власників підприємств, яке проявляється у непропорційних структурних співвідношеннях заробітної плати й прибутку.

Зовнішні (міжсекторні) протиріччя економічних інтересів суб' єктів різних секторів ринку знаходять прояв у міграції ДВ або іï міжсекторному перерозподілі (див. рис. 1). Як привило, мова йде про прибуткову складову ДВ (рис. 2). Відповідно до теорії логістичних ланцюгів, агент, що управляє ланцюгом, задає пропорції розподілу доданої вартості між ланками. Учені виділяють три інструменти модернізації учасників ланцюжка ДВ: (1) підвищення конкурентоспроможності виробника в межах даного місця в ланцюгу; (2) зміна місця даного виробника; (3) зміна ланцюга $[1$, с. 362].

Процес використання доданої вартості формує другий етап їі колообігу в ITP та включає фіскальний перерозподіл, споживання власником і реінвестування (див. рис. 1). Проведені дослідження довели, що секторна ДВ належить до категорії показників із високим ступенем регуляторної здатності: дві їі складові (заробітна плата й прибуток) формують базу оподаткування для розрахунку соціальних внесків і податку на прибуток; загальна іï величина є базою для податку на додану вартість. При цьому показник секторної ДВ має здатність до виміру податкової еластичності, дозволяючи визначати приріст (скорочення) перелічених податків у результаті впровадження регуляторних заходів, що змінюють одну або декілька компонентів ДВ $[12,13]$. У ході фіскального перерозподілу доданої вартості можуть виникати зовнішні протиріччя між економічними інтересами держави та суб' єктів господарювання, наслідком яких дуже часто $\epsilon$ заниження реальної бази оподаткування як спосіб зменшення податкового тиску.

Частина новоствореної вартості у звітному періоді споживається підприємцями для задоволення особистих потреб, а інша частина реінвестується, тобто спрямовується на забезпечення наступного етапу процесу формування ДВ, замикаючи пї колообіг в ITP (див. рис. 1). Питання визначення компонентів реінвестованої секторної доданої вартості (ДВ економічній літературі є малодослідженим. На наш погляд, до таких компонентів доцільно віднести секторну заробітну плату працівників у повному обсязі, оскільки вся вона забезпечує відтворення трудового потенціалу (3П $\mathbf{C}$ ); реінвестовану секторну амортизацію $\left(\mathbf{P}_{\mathbf{A c}}\right)$ - частину амортизаційних відрахувань, використаних у звітному періоді суб' єктами на оновлення необоротних активів; реінвестований секторний прибуток $\left(\mathbf{P}_{\Pi \mathbf{~}}\right)$ - обсяг капіталізованого прибутку в звітному періоді; реінвестовані специфічні ресурси $\left(\mathbf{P}_{\mathbf{C c}}\right)$, наприклад, частина орендних платежів, використаних суб' єктами сировинного сектору ринку на відновлення родючості грунтів:

$$
2 B_{\mathrm{Pc}}=3 \Pi_{\mathrm{C}}+\mathbf{P}_{\mathrm{Ac}}+\mathbf{P}_{\Pi c}+\mathbf{P}_{\mathrm{Cc}}
$$

Визначення пропорцій розподілу новоствореної вартості на споживання та реінвестування, в ході яких можуть виникати внутрішні протиріччя фінансових інтересів власників підприємств, залежить від сукупності внутрішніх і зовнішніх чинників, зокрема, стратегії розвитку господарюючих суб'єктів та їх об'єднань, поточної й прогнозної кон'юнктури ринку, державної політики тощо. Слід відзначити можливість впливу держави на процеси формування та використання ДВ у мезосистемі з метою забезпечення ефективного продукування і реінвестування новоствореної вартості в стратегічних товарних ринках, а також розв'язання внутрішніх і зовнішніх протиріч (див. рис. 1). Формування системи державного управління ДВ у ринковому вимірі створить передумови трансформації іiі стихійного руху у керований колообіг на базі досягнення цільових орієнтирів розвитку та узгодження різновекторних інтересів учасників процесу відтворення в ІТР.

Методологічний підхід до оцінки ефективності інтегрованого товарного ринку, що пропонується автором та є результатом проведених досліджень [12, $13,14]$, поєднує концептуальний та методичний базиси, складові яких наведено на рис. 2. Концептуальний базис формує теорія ресурсовідтворення у секторах ITP та колообіг секторної ДВ в мезосистемі (див. рис. 1), спрямовуючи фокус дослідження не тільки на оцінку процесу формування (продукування) новост-

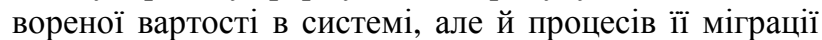
та використання, які в економічній теорії не отримали глибокого опрацювання.

Головною метою методичних положень є багаторівнева оцінка ефективності формування та ефективності використання доданої вартості за етапами іiі колообігу як методичний базис прийняття управлінських рішень для забезпечення збалансованого розвитку ITP, формування механізму державного управління доданою вартістю в стратегічних ринках країни. Невід'ємною складовою методологічного підходу є принципи оцінки ефективності функціонування ITP (див. рис. 2). Виділені принципи орієнтують вектор дослідження на об'єктивну оцінку ефективності функціонування секторів ITP і ринку в цілому з позиції економічних інтересів держави, а не окремих ринкових суб'єктів, на цільове визначення «розривів» у відтворювальному ланцюзі ДВ та практичній значимості методичних положень як бази для прийняття управлінських рішень щодо нівелювання (зменшення) таких «розривів». Методичний базис включає методичні положення оцінки ефективності функціонування інтегрованого товарного ринку, діагностику релевантного ринку як основу для прийняття управлінських рішень щодо методів і заходів регулювання, узгоджених із пріоритетами державної політики й стратегічними напрямами розвитку релевантного ринку, а також методичні положення оцінки ефективності регулювання ITP (див. рис. 2). 


\section{Коние $n$ ту уаний базис}

Теорія відтворення ресурсів у секторах ITP, колообіг секторної доданої вартості в мезосистемі Мета методичних положень оцінки ефективності функціонування ITP

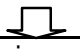

Багаторівнева оцінка ефективності формування та ефективності використання доданої вартості за етапами її колообігу в секторному та ринковому вимірі як методичний базис прийняття виважених управлінських рішень для забезпечення збалансованого розвитку ITP, формування дієвого механізму державного управління ДВ в стратегічних ринках країни

\section{Завдання методичних положень оцінки ефрективності функціонування ITP}

$$
\square
$$

1. Систематизація інформаційних потоків у розрізі головних напрямів оцінки

2. Аналіз ефективності формування ДВ у мезосистемі з акцентом на динаміку змін структури (ресурсної й секторної) показника, а також на міграцію новоствореної вартості між секторами ITP

3. Оцінка ефективності ресурсовикористання в ринковій мезосистемі на базі відтворювального підходу

4. Аналіз ефективності використання ДВ в ІТР з акцентом на фіскальне й відтворювальне використання

5. Визначення за результатами оцінки негативних тенденцій у розвитку ринку, «вузьких місць» у відтворювальному ланцюгу доданої вартості, напрямів і обсягів деформацій процесів відтворення, джерел їх виникнення

6. Прогнозування розвитку процесів і показників ефективності у секторах інтегрованого товарного ринку

\begin{tabular}{|c|c|}
\hline & Принципи оцінки ефрективності фрункціонування ITP \\
\hline $\begin{array}{l}\text { 1.Пріоритетність } \\
\text { економічних інтересів } \\
\text { держави }\end{array}$ & $\begin{array}{l}\text { дінка ефрективності функціонування ITP здійснюється не з позиції економічних інтересів окремих } \\
\text { б'єктів ринку, а держави як носія інтересів суспільства; даний принцип є головним і в прийнятті } \\
\text { равлінських рішень щодо селективного впливу на процеси продукування, міграції або використан } \\
\text { З у мезосистемі }\end{array}$ \\
\hline $\begin{array}{l}\text { 2. Системність і ком- } \\
\text { плексність }\end{array}$ & $\begin{array}{l}\text { Оцінка ефективності ITP як складної динамічної системи проводиться з урахуванням всіх внутрішніх і } \\
\text { зовнішніх зв'язків між елементами (секторами ринку) та їх взаємозалежності, забезпечуючи всебічне } \\
\text { дослідження причинних залежностей у ринковій системі }\end{array}$ \\
\hline $\begin{array}{l}\text { 3.Адекватність і гнуч- } \\
\text { кість }\end{array}$ & $\begin{array}{l}\text { Забезпечення можливості швидкого реагування та врахування змін у зовнішньому і внутрішньому } \\
\text { економічному просторі ІTР, відповідність способів і прийомів аналізу сучасним закономірностям } \\
\text { плинності ринкових процесів відтворення }\end{array}$ \\
\hline $\begin{array}{l}4.06 ' \epsilon t \\
\text { Hicmb }\end{array}$ & $\begin{array}{l}\text { нки повинна бути достовірною, а ії результати обґрунтовуватися точними } \\
\text { и }\end{array}$ \\
\hline 5. Дiєє & $\begin{array}{l}\text { Результати оцінки ефективності ITP повинні мати прикладне значення, слугувати базою для прийнят- } \\
\text { тя заходів щодо нівелювання (зменшення) деформацій процесів відтворення, для аналізу зворотної } \\
\text { реакції товарного ринку на заходи державного впливу }\end{array}$ \\
\hline 6. Цілеспрямованість & $\begin{array}{l}\text { Цільове визначення селективних «розривів» у відтворювальному ланцюзі ДВ, які є джерелом дезінтє } \\
\text { грації елементів системи або десоормацій в секторах ринку }\end{array}$ \\
\hline 7. $\mathrm{Ha}$ & $\begin{array}{l}\text { остійне удосконалення методик аналізу та використання передового світового досвіду щодо оцінн } \\
\text { рективності фрункціонування товарних ринків }\end{array}$ \\
\hline
\end{tabular}

7. Узагальнення та якісна оцінка результатів аналізу як база для прийняття управлінських рішень Me mодичний базис

\section{Методичні положення оцінки ефективності функціонування ITP. Головні етапи оцінки:}

1. Ідентифрікація релевантного ринку: товарні, територіальні та часові межі ринку, ємність, структура та головні суб'єкти ринку

2. Оиінка ефрективності ITP за допомогою множини різноаспектних показників:

2.1. Оцінка ефективності формування ДВ в мезосистемі: аналіз динаміки ДВ та її частки у випуску продукції в секторному та ринковому вимірі; оцінка ресурсної структури ДВ; оцінка міжсекторного перерозподілу ДВ; аналіз рівня використання ресурсного потенціалу.

2.2. Оцінка ефективності ресурсовикористання в мезосистемі: ефективність використання матеріальних і трудових ресурсів; аналіз виробничої залежності, автономії праці.

2.3. Оцінка ефрективності використання доданої вартості в мезосистемі: аналіз обсягів та динаміки фіскального використання ДВ; оцінка відтворювального використання новоствореної вартості.

3. Діагностика релевантного ринку, якісний аналіз причинно-наслідкових зв'язків, що визначають плинність процесів відтворення на ринку; міжсекторні баланси показників ефективності ITP; прогнозні сценарії розвитку ринку.

Пріоритети національної політики в ринковому вимірі, стратегічні орієнтири відтворювального розвитку 凸 інтегрованих товарних ринків в умовах відкритої економіки
1. Нормативно-правові
2. Фінансово-економічні
3. Адміністративні
4. Організаційні

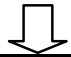

Методи державного регулювання

Методичні положення оцінки ефективності регулювання ITP: ефекти від впровадження механізмів регулювання (відтворювальний, податковий, соціальний); рентабельність впровадження механізмів регулювання ITP; вибір найефективнішого із сукупності альтернативних регуляторних механізмів

\footnotetext{
Рис. 2. Структурна схема методологічного підходу до оцінки ефективності функціонування інтегрованого товарного ринку *

*авторська розробка
} 
Таким чином, методичні положення оцінки ефективності ITP органічно вбудовані в методологічний фундамент ринкового дослідження і тісно взаємопов'язані з процесами діагностики, прогнозування, регулювання та управління ринком. Оціночну складову методичних положень, яка передбачає конструювання певних груп аналітичних показників, розглянемо більш детально.

Першим етапом оцінки ефективності функціонування ITP, як і загального ринкового аналізу, $\epsilon$ ідентифікація релевантного ринку, що передбачає визначення товарних, територіальних та часових меж ринку, його ємності, секторної структури та головних суб'єктів. Другий етап передбачає розрахунок множини трьох рівнів аналітичних показників для оцінки ефективності формування й використання доданої вартості, а також ефективності ресурсовикористання в мезосистемі (див. рис. 2). Слід відзначити існування двох підходів до визначення критерію ефективності економічних систем: (1) побудова єдиного універсального критерію; (2) формування сукупності критеріїв зміни та оцінки ефективності складних систем, які, маючи багатоцільовий характер, виходять за межі одноцільової моделі. У даному дослідженні реалізовано другий підхід шляхом конструювання системи аналітичних показників для оцінки ефективності функціонування ITP. Їх характеристики та формули розрахунку наведені автором в таблиці 1.

Периий рівень оціночної системи передбачає оиінку ефективності формування доданої вартості шляхом розрахунку та аналізу 4 груп показників: (1) аналіз динаміки ДВ та їі частки у випуску продукції в секторному та ринковому вимірі; (2) оцінка ресурсної структури новоствореної вартості; (3) оцінка iii міжсекторного перерозподілу; (4) аналіз рівня використання ресурсного потенціалу (див. табл. 1).

Таблиця 1

Система показників для оцінки ефективності функціонування інтегрованого товарного ринку

\begin{tabular}{|c|c|c|c|}
\hline $\begin{array}{l}\text { Етапи ана- } \\
\text { лізу }\end{array}$ & Показники & Характеристика & Формула розрахунку \\
\hline 1 & 2 & 3 & 4 \\
\hline \multicolumn{4}{|c|}{ 1. Оцінка ефективності формування доданої вартості в мезосистемі } \\
\hline \multirow{5}{*}{ 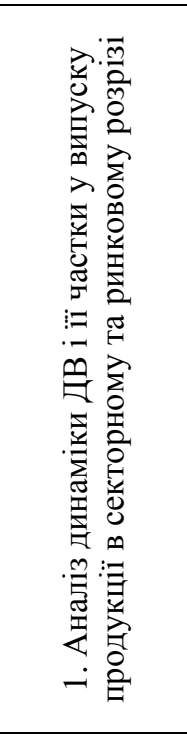 } & $\begin{array}{l}\text { Секторна додана } \\
\text { вартість (ДВ })\end{array}$ & $\begin{array}{l}\text { Відображає реальний внесок } \\
\text { кожного сектору в створення } \\
\text { доданої вартості в ITP }\end{array}$ & 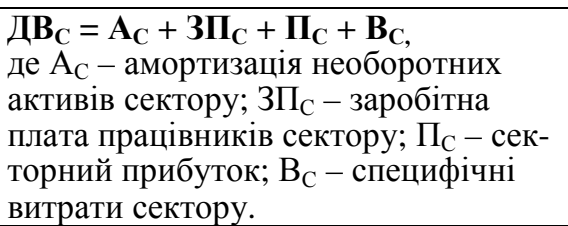 \\
\hline & $\begin{array}{l}\text { Ринкова додана вар- } \\
\text { тість (ДВ })\end{array}$ & $\begin{array}{l}\text { Загальна величина новостворе- } \\
\text { ної вартості в ITP }\end{array}$ & 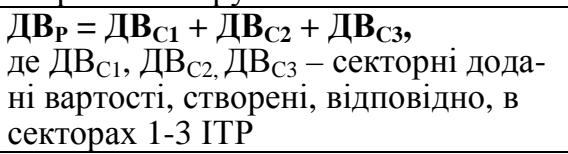 \\
\hline & $\begin{array}{l}\text { Частка ДВ у випус- } \\
\text { ку продукції } \\
\left(\mathbf{Ч}_{\text {дв }}\right)\end{array}$ & $\begin{array}{l}\text { Питома вага ДВ (секторної та } \\
\text { ринкової) у випуску продукції } \\
\text { (певного сектору або ринку) }\end{array}$ & 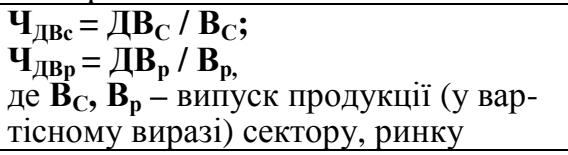 \\
\hline & $\begin{array}{l}\text { Відтворювальна } \\
\text { рентабельність про- } \\
\text { дукції }\left(\mathbf{P B}_{\mathbf{C}}\right)\end{array}$ & $\begin{array}{l}\text { Обсяг доданої вартості, що } \\
\text { припадає на } 1 \text { грн. витрат на } \\
\text { виробництво продукції (послуг) } \\
\text { певного сектору ITP }\end{array}$ & $\begin{array}{l}\mathbf{P B}_{\mathbf{C}}=\text { ДB }_{\mathbf{C}} / \mathbf{B T}_{\mathbf{C}}, \\
\text { де } \mathbf{B T}_{\mathbf{C}}-\text { витрати на виробництво } \\
\text { продукції (послуг) певного сектору } \\
\text { ITP }\end{array}$ \\
\hline & $\begin{array}{l}\text { Секторна ст } \\
\text { ДВ } \\
\end{array}$ & $\begin{array}{l}\text { ів ІТР у ринковій } \\
\text { сті }\end{array}$ & $\begin{array}{l}\mathbf{Y}_{\mathrm{C} 1}=Д \mathrm{~B}_{\mathrm{C} 1} / Д_{\mathrm{B}_{\mathrm{P}}} ; \mathbf{4}_{\mathrm{C} 2}=Д \mathrm{~B}_{\mathrm{C} 2} / Д \mathrm{~B}_{\mathrm{P}} ; \\
\mathbf{4}_{\mathrm{C} 3}=\text { ДВ }_{\mathrm{C} 3} / Д_{\mathrm{B}}\end{array}$ \\
\hline \multirow{4}{*}{ 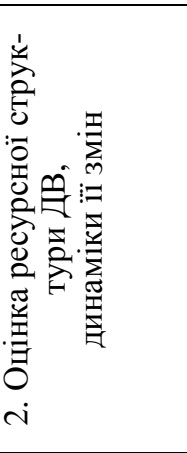 } & $\begin{array}{l}\text { Капіталомісткість } \\
\text { доданої вартості } \\
\left(\mathbf{K}_{\text {дв }}\right)\end{array}$ & $\begin{array}{l}\text { Питома вага витрат на віднов- } \\
\text { лення необоротних активів пе- } \\
\text { вного сектору ITP }\end{array}$ & $\begin{array}{l}\mathbf{K}_{\text {дв }}=\mathbf{A}_{\mathbf{C}} / \text { ДВс, } \\
\text { де } \mathrm{A}_{\mathrm{C}}-\text { амортизація необоротних } \\
\text { активів певного сектору ITP }\end{array}$ \\
\hline & $\begin{array}{l}\text { Трудомісткість до- } \\
\left.\text { даної вартості ( } \mathbf{T}_{\text {дв }}\right)\end{array}$ & $\begin{array}{l}\text { Частка особистих доходів пра- } \\
\text { цівників; величина витрат на } \\
\text { оплату праці для створення } \\
1 \text { грн. ДВ } \\
\end{array}$ & $\begin{array}{l}\mathbf{T}_{\text {дв }}=\mathbf{3} \boldsymbol{\Pi}_{\mathbf{C}} / \text { ДВс, } \\
\text { де ЗП } \\
\text { певного секоборуа плата працівників } \\
\text { пев }\end{array}$ \\
\hline & $\begin{array}{l}\text { Частка прибутку } \\
\left(\mathbf{Ч}_{\Pi}\right)\end{array}$ & $\begin{array}{l}\text { Частка прибутку у доданій вар- } \\
\text { тості, створюваній певним сек- } \\
\text { тором ITP }\end{array}$ & $\begin{array}{l}\mathbf{Y}_{\boldsymbol{\Pi}}=\Pi_{\mathbf{C}} / \text { ДВс, } \\
\text { де } \Pi_{\mathrm{C}}-\text { секторний прибуток }\end{array}$ \\
\hline & $\begin{array}{l}\text { Частка специфіч- } \\
\text { них витрат }\left(\mathbf{Ч}_{\mathbf{C B}}\right)\end{array}$ & $\begin{array}{l}\text { Питома вага специфічних ви- } \\
\text { трат у секторній ДВ }\end{array}$ & $\begin{array}{l}\mathbf{Y}_{\mathbf{C B}}=\mathbf{B}_{\mathbf{C}} / \text { ДВс, де } \mathrm{B}_{\mathrm{C}}-\text { секторні } \\
\text { специфічні витрати. }\end{array}$ \\
\hline \multirow{2}{*}{ 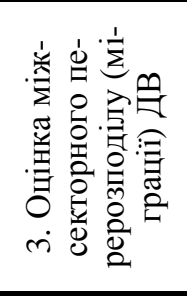 } & $\begin{array}{l}\text { Коефіціснти } \\
\text { співвідношення } \mathbf{P}_{\text {дв }} \\
\text { різних секторів }(\mathbf{K 1}, \\
\mathbf{K 2}, \mathbf{K 3})^{* *}\end{array}$ & $\begin{array}{l}\text { Глибина різниць рентабельнос- } \\
\text { ті доданої вартості у секторно- } \\
\text { му вимірі; напрям міграції при- } \\
\text { бутку в ITP }\end{array}$ & 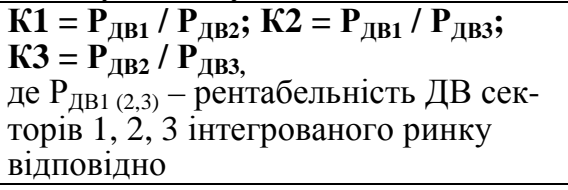 \\
\hline & $\begin{array}{l}\text { Частка непродуктив- } \\
\text { ної компоненти } \\
\left(\mathbf{Y}_{\mathbf{H}}\right)^{* *}\end{array}$ & $\begin{array}{l}\text { Питома вага непродуктивної } \\
\text { компоненти ДВ у новостворе- } \\
\text { ній вартості сектору } \\
\end{array}$ & $\begin{array}{l}\mathbf{Y}_{\mathbf{H}}=\text { ДВ } \\
\text { де ДВ } / \text { ДВс } \\
\text { складової партість непного сектору ITP }\end{array}$ \\
\hline
\end{tabular}


Продовження табл. 1

\begin{tabular}{|c|c|c|c|}
\hline $\begin{array}{c}\text { Етапи } \\
\text { аналізу }\end{array}$ & Показники & Характеристика & Формула розрахунку \\
\hline 1 & 2 & 3 & 4 \\
\hline \multirow{2}{*}{ 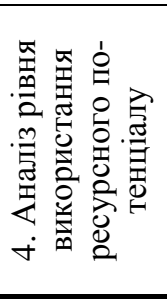 } & $\begin{array}{l}\text { Коефіцієнт викори- } \\
\text { стання потенціалу } \\
\text { сектору (Пс) }\end{array}$ & $\begin{array}{l}\text { Питома вага секторної доданої } \\
\text { вартості, фактично створеної в } \\
\text { звітному періоду, до потенцій- } \\
\text { но можливої ДВ }\end{array}$ & $\begin{array}{l}\Pi_{\mathbf{C}}=\text { ДВ }_{\mathbf{C}} / \text { ДВ }_{\text {Пс }}, \\
\text { де ДВ Пс }- \text { потенційно можлива вели- } \\
\text { чина секторної доданої вартості }\end{array}$ \\
\hline & $\begin{array}{l}\text { Коефіцієнт викори- } \\
\text { стання потенціалу } \\
\text { ITP }\left(\boldsymbol{\Pi}_{\mathbf{P}}\right)^{* *}\end{array}$ & $\begin{array}{l}\text { Питома вага ринкової ДВ, фак- } \\
\text { тично виробленою мезосисте- } \\
\text { мою, до потенційно можливого } \\
\text { рівня показника }\end{array}$ & $\begin{array}{l}\boldsymbol{\Pi}_{\mathbf{P}}=\text { ДВ }_{\mathbf{P}} / \text { ДВ }_{\text {Пр }}, \\
\text { де ДВ Пр }- \text { потенційно можлива вели- } \\
\text { чина ринкової доданої вартості }\end{array}$ \\
\hline \multicolumn{4}{|c|}{ 2. Оцінка ефективності ресурсовикористання в мезосистемі } \\
\hline \multirow{3}{*}{ 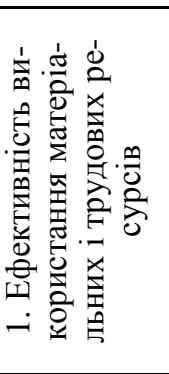 } & $\begin{array}{l}\text { Секторна фондовід- } \\
\text { дача } \mathbf{\Phi o}_{\mathbf{c}}\end{array}$ & $\begin{array}{l}\text { Додана вартість, створювана в } \\
\text { секторах ITР з використанням } \\
1 \text { грн. основних засобів }\end{array}$ & $\begin{array}{l}\text { Фо }_{\mathbf{c}}=\text { ДВ }_{\mathbf{C}} / \mathbf{O 3}_{\mathbf{C}}, \quad \text { де O3 } \mathrm{C} \text { вартість } \\
\text { основних засобів у певному секторі } \\
\text { ринку }\end{array}$ \\
\hline & $\begin{array}{l}\text { Секторна продукти- } \\
\text { вність праці (ППс) }\end{array}$ & $\begin{array}{l}\text { Величина вартості, що створю- } \\
\text { ється в процесі виробництва } 1 \\
\text { працівником }\end{array}$ & $\begin{array}{l}\text { ППс }=\text { ДВ }_{\mathbf{C}} / \mathbf{Y}_{\mathbf{C}}, \quad \text { де } \mathrm{Ч}_{\mathrm{C}}-\text { чисель- } \\
\text { ність працівників у секторах інтег- } \\
\text { рованого ринку }\end{array}$ \\
\hline & $\begin{array}{l}\text { Секторний коефіці- } \\
\text { єнт оборотності ви- } \\
\text { роб-ничих запасів } \\
\text { (Коб) }\end{array}$ & $\begin{array}{l}\text { Величина створеної ДВ з вико- } \\
\text { ристання } 1 \text { грн. уречевленої } \\
\text { (перенесеної) праці у виробни- } \\
\text { чих запасах }\end{array}$ & $\begin{array}{l}\text { Коб = ДВ } \mathbf{C} \text { / } \mathbf{B} \mathbf{3}_{\mathbf{C}}, \text { де } \mathrm{B} 3_{\mathrm{C}}-\text { вартість } \\
\text { виробничих запасів у певному сек- } \\
\text { торі ринку }\end{array}$ \\
\hline \multirow{3}{*}{ 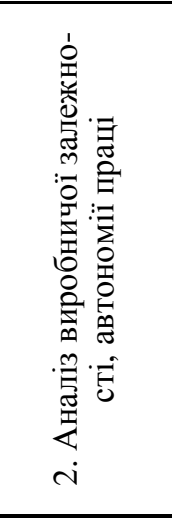 } & $\begin{array}{l}\text { Секторна матеріало- } \\
\text { віддача }\left(\mathbf{M B}_{\mathbf{C}}\right)\end{array}$ & $\begin{array}{l}\text { Автономія праці; величина ДВ, } \\
\text { що припадає на } 1 \text { грн. уречев- } \\
\text { леної праці }\end{array}$ & $\mathbf{M B}_{\mathrm{C}}=Д \mathbf{B}_{\mathrm{C}} / \mathbf{M B}_{\mathrm{C}}$ \\
\hline & $\begin{array}{l}\text { Секторна матеріа- } \\
\text { ломісткість }\left(\mathbf{M}_{\mathbf{M c}}\right)\end{array}$ & $\begin{array}{l}\text { Залежність виробничого проце- } \\
\text { су від зовнішніх джерел; розмір } \\
\text { перенесеної вартості для про- } \\
\text { дукування } 1 \text { грн. ДВ }\end{array}$ & $\begin{array}{l}\mathbf{M м}_{\mathrm{C}}=\mathbf{M B}_{\mathbf{C}} / \text { ДВ } \mathbf{B}_{\mathbf{C}} \text {, де } \\
\text { MB }_{\mathrm{C}}-\text { вартість матеріальних витрат } \\
\text { у секторах ринку }\end{array}$ \\
\hline & $\begin{array}{l}\text { Секторна сирови- } \\
\text { номісткість }\left(\mathbf{C}_{\mathbf{M c}}\right) \text {, } \\
\text { паливомісткість } \\
\left(\boldsymbol{\Pi}_{\mathbf{M c}}\right) \text {, } \\
\text { енергомісткість } \\
\left(\mathbf{E}_{\mathbf{M c}}\right)\end{array}$ & $\begin{array}{l}\text { Витрати певних видів матеріа- } \\
\text { лів (сировини, палива та елект- } \\
\text { роенергії), що припадають на } 1 \\
\text { грн. створеної ДВ у певному } \\
\text { секторі ITP }\end{array}$ & 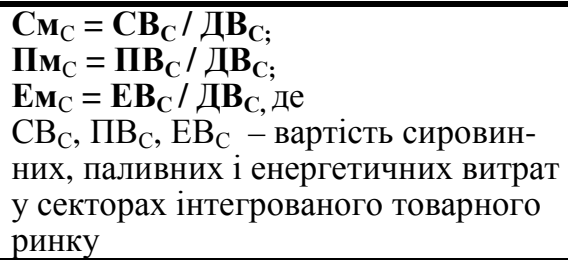 \\
\hline \multicolumn{4}{|c|}{ 3. Оцінка ефективності використання доданої вартості в мезосистемі } \\
\hline \multirow{4}{*}{ 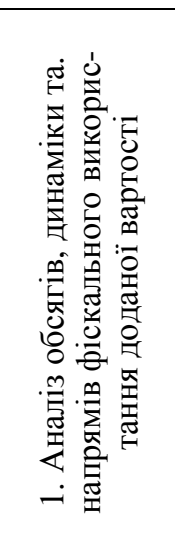 } & $\begin{array}{l}\text { Податкомісткість } \\
\text { доданої вартості } \\
(\text { Пдв) }\end{array}$ & $\begin{array}{l}\text { Величина податкових надхо- } \\
\text { джень, що припадає на } 1 \text { грн. } \\
\text { ДВ у секторному та ринковому } \\
\text { розрізі }\end{array}$ & $\begin{array}{l}\boldsymbol{\Pi}_{\text {Двс }}=\boldsymbol{\Pi}_{\mathbf{C}} / \text { ДВс; } \\
\boldsymbol{\Pi}_{\text {ДВр }}=\Pi_{\mathbf{P}} / \text { ДВр}, \\
\text { де Пс, Пр - Податкові надходження } \\
\text { сектору, ринку }\end{array}$ \\
\hline & $\begin{array}{l}\text { Коефіцієнт } \\
\text { еластичності подат- } \\
\text { ків за ДВ } \\
\left(\mathbf{E}_{\Pi}\right)^{* *}\end{array}$ & $\begin{array}{l}\text { Відсоткова зміна обсягів подат- } \\
\text { кових надходжень від суб’єктів } \\
\text { сектору (ринку) при зміні дВ } \\
\text { на } 1 \%\end{array}$ & $\begin{array}{l}\mathbf{E} \Pi_{c}=\% \Delta \Pi c / \% \Delta Д В c ; \\
\mathbf{E} \Pi_{p}=\% \Delta \Pi p / \% \Delta Д В p\end{array}$ \\
\hline & $\begin{array}{l}\text { Секторна структура } \\
\text { податків }\end{array}$ & $\begin{array}{l}\text { Частка секторів ITР у загальній } \\
\text { сумі ринкових податкових над- } \\
\text { ходжень }\end{array}$ & $\begin{array}{l}\mathbf{Y}_{\mathrm{C} 1}=\Pi_{\mathrm{C} 1} / \Pi_{\mathrm{P}} ; \mathbf{Y}_{\mathrm{C} 2}=\Pi_{\mathrm{C} 2} / \Pi_{\mathrm{P}} ; \mathbf{Y}_{\mathrm{C} 3}= \\
\Pi_{\mathrm{C} 3} / \Pi_{\mathrm{P}}\end{array}$ \\
\hline & $\begin{array}{l}\text { Видова структура } \\
\text { податків }\end{array}$ & $\begin{array}{l}\text { Частка певних податків у зага- } \\
\text { льній сумі в секторному та ри- } \\
\text { нковому розрізі }\end{array}$ & $\begin{array}{l}\mathbf{Y}_{\mathbf{C B}}=\mathbf{C B} / \text { П; } \mathbf{Ч}_{\text {Пдв }}=\text { ПДВ } / \text { П; } \mathbf{Ч}_{\text {Пп }} \\
=\text { ПП } / \text { П, де СВ - соціальний вне- } \\
\text { сок; ПДВ - податок на додану вар- } \\
\text { тість; ПП - податок на прибуток. }\end{array}$ \\
\hline \multirow{2}{*}{ 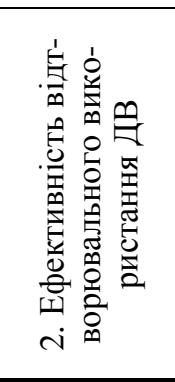 } & $\begin{array}{l}\text { Додана вартість ре- } \\
\text { інвестована } \\
(\text { ДВ })\end{array}$ & $\begin{array}{l}\text { Частина новоствореної вартос- } \\
\text { ті, спрямованої на ресурсне } \\
\text { забезпечення наступного про- } \\
\text { цесу відтворення певного сек- } \\
\text { тору або ринку в цілому }\end{array}$ & 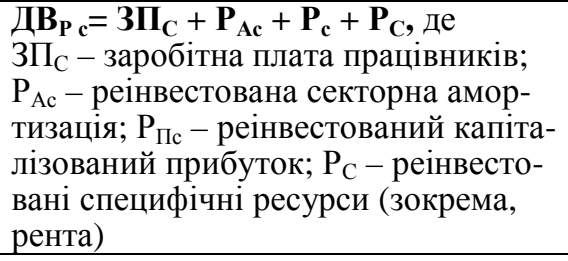 \\
\hline & $\begin{array}{l}\text { Секторна структура } \\
\text { ДВ }_{\mathbf{P}}\end{array}$ & $\begin{array}{l}\text { Частка секторів ІТР у загальній } \\
\text { сумі ринкової реінвестованої } \\
\text { доданої вартості }\end{array}$ & 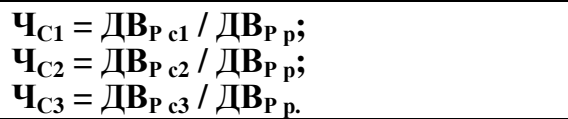 \\
\hline
\end{tabular}


Продовження табл. 1

\begin{tabular}{|c|c|c|c|}
\hline $\begin{array}{c}\text { Етапи } \\
\text { аналізу }\end{array}$ & Показники & Характеристика & Формула розрахунку \\
\hline 1 & 2 & 3 & 4 \\
\hline 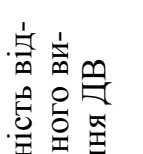 & $\begin{array}{l}\text { Ресурсна структура } \\
\text { ДВ }_{\mathbf{P}}\end{array}$ & $\begin{array}{l}\text { Питома вага реінвестованих } \\
\text { ресурсів у загальній сумі ДВ } \\
\text { секторному та ринковому роз- } \\
\text { різі }\end{array}$ & 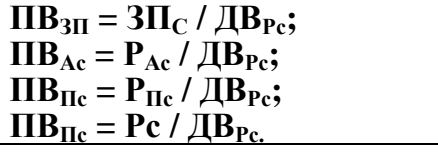 \\
\hline 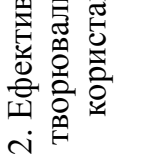 & $\begin{array}{l}\text { Коефіцієнт реінвес- } \\
\text { тування доданої } \\
\text { вартості }\left(\mathbf{K}_{\mathbf{P д в}}\right)\end{array}$ & $\begin{array}{l}\text { Питома вага реінвестованої ДВ, } \\
\text { у загальній величині вартості, } \\
\text { створеної в певних секторах } \\
\text { (або ITP) за звітний період }\end{array}$ & 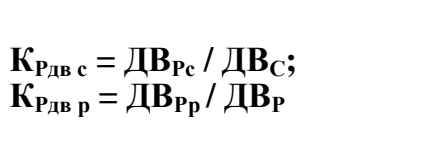 \\
\hline
\end{tabular}

зозроблено автором із використанням джерел [1-9, 12-16];

*авторська розробка

Ядром першої групи аналітичних показників є частка доданої вартості (секторної або ринкової) у випуску продукції (Ч $\left.\mathbf{Ч}_{\text {дв}}\right)$ та відтворювальна рентабельність продукції (PBс). В теорії інтеграційного аналізу $\mathbf{Ч}_{\text {дв }} \epsilon$ одним із традиційних показників для вимірювання та моніторингу вертикальної інтеграції на рівні підприємств. Цей індекс варіює від 0 до 1, де 1 представляє максимально можливий рівень інтегро-

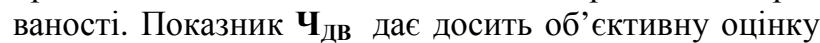
динаміки вертикальної інтеграції в галузі, однак не може використовуватися для прямого порівняння галузей, що значно відрізняються між собою за ступенем залежності від продуктів проміжного споживання [15]. Відтворювальна рентабельність визначає обсяг ДВ, що припадає на 1 грн. витрат на виробництво продукції (послуг) певного сектору інтегрованого ринку; може розраховуватися як у секторному, так i ринковому розрізі. Показник РВс, як правило, перевищує значення показника рентабельності продукції. За умови збитковості виробництва та від'ємного значення рентабельності продукції, показник відтворювальної рентабельності має позитивне значення, відображаючи величину питомої ДВ та ефективність використання ресурсів у системі.

Друга група показників першого рівня оцінює ресурсну структуру новоствореної вартості, визначаючи питому вагу іiі компонентів у загальній величині (див. табл. 1). В ході оцінки можна здійснювати як секторний і ринковий аналіз динаміки показників капіталомісткості й трудомісткості доданої вартості, часток прибутку й специфічних витрат, так і міжсекторні й міжринкові порівняння їх величин, що значно розширює аналітичне поле дослідження. Третя група показників орієнтована на оцінку міжсекторного перерозподілу (міграції) новоствореної вартості в ITP. Запропоновані коефіцієнти співвідношення рентабельності доданої вартості $\left(\mathbf{P}_{\text {дв }}\right)$ різних секторів інтегрованого товарного ринку дозволяють визначити глибину різниць у рівнях секторної доходності та головні напрями міграції прибутку в мезосистемі. Завершує оціночну систему першого рівня коефіцієнт використання потенціалу сектору або ринку в цілому, як відношення фактично створеної ДВ до потенційно можливої іï величини (див. табл. 1). Для визначення останньої можна використати показники рівня вико- ристання виробничої потужності суб'єктів певного сектору ринку. Коефіцієнти використання потенціалу дозволяють визначити резерви зростання продукування ДВ у секторному та ринковому вимірі.

Другий рівень оціночної системи передбачає аналіз ефективності ресурсовикористання в ринковій мезосистемі (див. табл. 1), що базується на теорії продуктивності факторів виробництва. Найбільш універсальним визначенням категорії «продуктивність», прийнятним для економічних систем різних рівнів, $\epsilon$ трактування, дане Д. С. Синком: «Продуктивність це відношення кількості продукції, виробленої певною системою за даний період часу, до кількості ресурсів, спожитих для створення виробництва цієї продукції за той же період» [9, с.125]. Слід відзначити, що існування різних методичних підходів до визначення продуктивності факторів виробництва, які змінюють межі і тип досліджуваних систем, не змінює основний зміст універсальної дефініції.

В основу категорії «ефективність ITP» нами закладено продуктивність використання ресурсів для досягнення відтворювального розвитку ринку [14, c. 66], що визначає доцільність побудови окремого рівня для оцінки ефективності ресурсовикористання в системі. Оцінка продуктивності факторів виробництва передбачає множинність свого числового представлення, утворюючи систему показників ефективності, які можуть бути приватними, багатофакторними й узагальнюючими. Для їх розрахунку в економічному аналізі, як правило, використовують показники чистої виручки від реалізації продукції [5, 8]. У відтворювальному методичному підході автором сконструйовано систему показників для оцінки ефективності ресурсовикористання на базі доданої вартості. Оскільки показник доданої вартості не містить перенесеної (уречевленої) праці, то його використання для аналізу економічних систем на мікро-, мезо- та макрорівнях дозволить оцінити величину власних витрат, понесених суб' єктами господарювання певних секторів економіки або інтегрованих ринків, а також структуру секторного доходу, що підвищить аналітичну цінність такого аналізу, розширить можливості його використання в ході прийняття управлінських рішень.

Другий рівень оціночної системи передбачає аналіз двох груп аналітичних показників (див. 
табл. 1). Перша група орієнтована на оцінку ефективності використання матеріальних і трудових ресурсів та включає показники секторної фондовіддачі, продуктивності праці й секторний коефіцієнт оборотності виробничих запасів. Слід підкреслити, що показник продуктивності праці, обчислений за допомогою ДВ, $\epsilon$ найбільш точним; він визначає величину вартості, створеної в процесі виробництва одним працівником.

Друга група орієнтована на оцінку виробничої залежності та автономії праці шляхом розрахунку показників секторної матеріаловіддачі та матеріаломісткості, а також приватних показників матеріаломісткості. Показник секторної матеріаловіддачі визначає обсяг ДВ, що припадає на 1 грн. уречевленої (перенесеної) праці, і характеризує автономію праці. Показник матеріаломісткості, розрахований як відношення уречевленої праці до доданої вартості, характеризує залежність суб' єктів певного сектору ITP від зовнішнього середовища, відтак, його можна ідентифікувати як коефіцієнт виробничої залежності. Приватними показниками матеріаломісткості продукції $€$ сировиномісткість, паливомісткість та енергомісткість [8, с. 336]; вони можуть використовуватися для оцінки економічного ефекту дематеріалізації в ринковому розрізі, що визначає їх практичну значимість і доцільність включення в систему.

Для оцінки ефективності ресурсовикористання в мезосистемі використовують динамічні й статичні коефіцієнти продуктивності факторів виробництва. Статичні коефіцієнти представляють відношення обсягу ДВ до витрат певних видів факторів виробництва за аналізований період. Динамічні індекси отримують шляхом ділення статичного коефіцієнта за звітний період на аналогічний коефіцієнт попереднього періоду; отриманий при цьому безрозмірний показник відображає зміну продуктивності у часі. Відповідно, аналіз показників другого рівня системи передбачає розрахунок як статичних, так і динамічних показників у секторному розрізі.

Третій рівень оціночної системи передбачає оцінку ефективності використання доданої вартості (див. табл. 1) відповідно до другого етапу ії колообігу в мезосистемі (див. рис. 1) з акцентом на податкове й відтворювальне використання. Перша група показників третього рівня оріснтована на оцінку обсягів, динаміки та структури податкових надходжень, базою нарахування яких є компоненти ДВ і ії загальна величина. Ядром даної групи є інноваційні показники, запропоновані автором: податкомісткість доданої вартості та коефіцієнт еластичності податків за ДВ. Перший показник визначає величину податкових надходжень, що припадає на 1 грн. новоствореної вартості; може розраховуватися як для окремих секторів, так і інтегрованого ринку в цілому. Другий показник дозволяє оцінити взаємозалежність між обсягами продукування ДВ у мезосистемі та величиною податкових надходжень від їі суб' єктів. Коефіцієнт податкової еластичності показує відсоткову зміну податкових надходжень від суб'єктів сектору або ринку при зміні показника ДВ на $1 \%$. Податкові надходження за доданою вартістю можуть бути еластичними, коли коефіцієнт податкової еластичності більший за 1, i нееластичними, коли коефіцієнт еластичності менший за 1 [12, с. 145]. Даний показник має прикладне значення, дозволяючи двоєдино оцінювати ефективність регуляторних заходів: 3 позиції економічних інтересів держави (зростання податків) і суб'єктів ринку (збільшення продукування ДВ).

Друга група показників третього рівня передбачає оцінку ефективності відтворювального використання новоствореної вартості шляхом аналізу обсягів і динаміки реінвестованої ДВ, їі секторної та ресурсної структури, статичних і динамічних коефіцієнтів реінвестування доданої вартості (див. табл. 1). Даний коефіцієнт визначає питому вагу реінвестованої ДВ у загальній величині вартості, створеної в певних секторах або ITP в цілому, за звітний період. Якщо значення коефіцієнту реінвестування ДВ $є$ меншим 1, то це $\epsilon$ свідченням звуженого відтворення ресурсів у системі, надмірного податкового навантаження та споживання значної частини прибутку власниками підприємств. Зміна податкової політики держави та політики розподілу прибутку суб'єктів ринку призводять до зміни коефіцієнту реінвестування доданої вартості. Значення показника більше 1 свідчить про розширене відтворення ресурсів у секторах та ITP в цілому, зростання обсягів внутрішнього виробництва, значний рівень капіталізації прибутку тощо. За своєю природою коефіцієнт реінвестування ДВ є показником рентабельності, який дозволяє оцінити поточну політику розподілу новоствореної вартості в секторному та ринковому розрізі. Найбільш бажаним 3 позиції державного менеджменту є значення коефіцієнту, наближене до 1, та його зростання у часі, що свідчить про стабільність фінансового забезпечення кожного наступного етапу процесу формування ДВ та відтворювального розвитку інтегрованого товарного ринку.

Третій етап оцінки ефективності функціонування ITP - діагностика релевантного ринку - передбачає більш високий рівень аналізу причиннонаслідкових зв'язків, що визначають різні аспекти формування та використання ДВ у мезосистемі. На даному етапі доцільними є побудова та оцінка міжсекторних балансів доданої вартості, матеріаловіддачі, продуктивності праці, податкових надходжень, реінвестованої ДВ, які дозволяють здійснити глибинні міжсекторні порівняння показників та визначити «вузькі місця» у ринковому процесі відтворення. Результати якісного аналізу формують аналітичну базу для моделювання прогнозних сценаріїв розвитку ITP, які, в свою чергу, визначають вибір методів державного регулювання 3 урахуванням стратегічних орієнтирів відтворювального розвитку ринків в умовах відкритої економіки (див. рис. 2).

Висновки та перспективи подальших досліджень. Головна ідея відтворювального методичного підходу полягає у визначенні деформацій в процесі формування та використання ДВ за етапами ії колоообігу в мезосистемі, непропорційності міжсекторного перерозподілу новоствореної вартості, ступеня реалізації фінансових інтересів основних учасників проце- 
су відтворення (суб'єктів ринку, працівників, держави) в контексті їх узгодження.

До переваг відтворювального методичного підходу оцінки ефективності функціонування ITP слід віднести наступне:

1) багаторівнева оцінка динаміки і структури доданої вартості за етапами їі колообігу в мезосистемі, напрямів і обсягів міжсекторного перерозподілу ДВ;

2) можливість проведення порівняльного аналізу в секторному та ринковому вимірі, що дозволяє визначати латентні деформації процесів відтворення, більшість яких виникає при переміщенні товарно-фінансових потоків від одного сектору ITP до іншого;

3) об'єктивна оцінка ефективності ресурсовикористання в мікро- та мезосистемах, можливість визначення структурних зрушень у випуску й реалізації продукції;

4) висока регуляторна здатність підібраних показників, можливість їх використання в якості наукового обгрунтування управлінських рішень;

5) гнучкість методики, іiі висока адаптивність до нових умов дослідження, зокрема, зміни завдань державного управління, розширення інформаційної бази, врахування специфіки процесів відтворення певних ринків тощо.

Користувачами відтворювального методичного підходу до оцінки ефективності ITP можуть бути державні й регіональні органи влади, а також суб'єкти господарювання та їх різноманітні інтегровані об'єднання.

Прикладне значення авторського методичного підходу визначається можливістю його використання для оцінки ефективності функціонування мікро- та мезоекономічних систем. Сьогодні цільовий орієнтир діяльності суб'єктів господарювання (зростання прибутку) не співпадає 3 цільовим вектором держави та суспільства в цілому (зростання ВВП), обумовлюючи необхідність зміни основного критерію ефективності мікросистем 3 прибутку на додану вартість як показник, що поєднує економічні інтереси ринкових суб'єктів, працівників і держави. Вважаємо, що додана вартість повинна зайняти належне місце в аналізі ефективності діяльності підприємств, методичну основу якого може сформувати розроблена трьохрівнева система показників (див. табл. 1), адаптована до умов мікросистем. Результати аналізу доданої вартості суб'єктів ринку та їх об'єднань орієнтовані на підвищення ефективності управлінських рішень, що приймаються на основі такого аналізу, вдосконалення діючої системи управління новоствореною вартістю.
Забезпечення ефективного функціонування стратегічних товарних ринків країни обумовлює необхідність розширення методичного базису для ринкового аналізу, що здійснюється державними та регіональними органами влади, за рахунок такої складової, як оцінка ринкових процесів відтворення на основі показника доданої вартості. Відтворювальний методичний підхід може знайти практичне використання в аналітичній та управлінській діяльності відповідних департаментів профільних Міністерств у ринковому розрізі. Проведені дослідження доводять можливість використання авторського методичного підходу для оцінки ефективності селективних заходів держави та моделювання прогнозних сценаріїв розвитку релевантного ринку [16].

Впровадження розробленого методичного підходу дозволить поглибити ринковий аналіз, зокрема, оцінити динаміку змін обсягів і структури доданої вартості товарів за етапами логістичного ланцюга; визначити деформації у міжсекторному перерозподілі, у фіскальному та відтворювальному використанні ДВ; здійснювати моніторинг та управління взаємозв'язком між різновекторними економічними інтересами ринкових суб'єктів та держави й суспільства 3 метою їх узгодження; дослідити зв'язок ринкової доданої вартості 3 продовольчої безпекою держави у контексті обгрунтування заходів щодо іiі забезпечення; підвищити ступінь стабілізуючого впливу держави на ринкові процеси відтворення; оцінити ефективність регуляторних заходів у площині економічних інтересів держави, підприємств та їх працівників; удосконалити механізм державного управління ДВ в стратегічних товарних ринках країни.

Наукова новизна проведеного дослідження полягає в удосконаленні теоретико-методичних положень щодо оцінки ефективності функціонування інтегрованого товарного ринку, які базуються на теорії колообігу секторної доданої вартості в мезосистемі з акцентом на пропорційність ії перерозподілу між секторами ринку та учасниками процесу відтворення, трьохрівневій оціночній системі показників, у т.ч. інноваційних (зокрема, відтворювальна рентабельність продукції, податкомісткість доданої вартості, коефіцієнт еластичності податків за доданою вартістю та ін.), що дозволяють визначити сучасні деформації у формуванні та використанні ДВ, цілеспрямовано зорієнтувати регуляторні заходи держави на їх зменшення (нівелювання). Наближення відтворювального методичного підходу до практичного застосування суб'єктами ринку, їх інтегрованими об'єднаннями, регіональними й державними органами влади формує перспективу подальших досліджень.

\section{Література}

1. Авдашева С. Б. Модернизация предприятий в цепочках добавленной стоимости / С. Б. Авдашева, И. А. Буданов, В.В. Голикова, А.А. Яковлев // Экономический журнал ВШЭ. - 2005. - №3. - С.361-377.

2. Булыга Р. Добавленная стоимость как целевой критерий / Р. Булыга, П. Кохно // Экономист. - 2007. №10. - C. $68-76$. 
3. Грідчіна М. В. Про додану вартість як показник результатів діяльності сучасних корпорацій / М. В. Грідчіна // Наукові праці МАУП. - 2013. - Вип. 1(36). - С. 126-129.

4. Іваненко В. О. Додана вартість як об’єкт аналізу статистичної звітності промислових підприємств 3 виробництва продукції / В. О. Іваненко // Проблеми теорії та методології бухгалтерського обліку, контролю і аналізу. - 2012. - № 1(22). - С. 122-130.

5. І Ізмайлова К. В. Фінансовий аналіз / К. В. Ізмайлова. - К.: МАУП, 2001. - 152 с.

6. Коваленко О.В. Додана вартість у контексті національної продовольчої безпеки / О. В. Коваленко // Економіка та держава. - 2015. - №4. - C. 98 - 102.

7. Lysyuk, V. M. (2014). Organization of the commodity market: theory and practice: monograph, Saarbrucken, Deutsehland: LAP LAMBERT Academic Publishing, 224.

8. Савицкая Г.В. Анализ хозяйственной деятельности предприятия / Г.В. Савицкая. - [7-е изд., испр.]. Минск: ООО «Новое знание», 2002. - 703 с.

9. Синк Д. С. Управление производительностью: планирование, измерение и оценка, контроль и повышение / Д. С. Синк; пер. с англ. - М.: Прогресс, 1989. - 528 с.

10. Contemporary Encyclopedia (2017). Retrieved from http://enc-dic.com/word/d/Dobavlennaya-stoimost23022.html.

11. Economic dictionary (2017). Retrieved from mirslovarei.com/ content_eco/.

12. Нікішина О. В. Методичні засади критеріальної оцінки відтворювальних процесів на інтегрованому зерновому ринку України [Електроний ресурс] / О. В. Нікішина // Економіка: реалії часу. - 2014. - №2 (12). C.139-149. Режим доступу: http://economics.opu.ua/files/archive/2014/No2/139-149.pdf.

13. Nikishyna, O. V. (2014). Criterion of Value Added in Assessing Efficiency of Integrated Markets Grain and Products his Processing in Ukraine, Nauka i Studia, 20 (130), 52 - 57.

14. Нікішина О. В. Методичний підхід до оцінки ефективності суб'єктів інтегрованого товарного ринку [Електроний ресурс] / О.В. Нікішина // Формування потенціалу економічного розвитку промислових підприємств: III міжн. наук.-практ. інтернет-конф., 27-28 квітня 2017 р.: тези допов. - Одеса: ОНПУ, 2017. C. 66-67. Режим доступу: http://economics.opu.ua/files/science/form ek rozv/2017/66.pdf

15. Економічна програма для України / Німецька консультативна група з питань економічних реформ при Уряді України. - К.: Ін-т екон. дослідж. та політ. консультацій, 2004. - 109 с.

16. Nikishyna, O. V. (2017). Measures for increase efficiency Ukrainian market of bread and bakery products. Actual problems of economics: theory and practice: VII International scientific conference, Jun 3 2017: theses report. Vinnitsa: LLC “Nilan-Ltd”, 25-30.

Стаття надійшла 01.06.2017

Стаття прийнята до друку 14.06.2017

Доступно в мережі Internet 30.09.2017

\author{
Никишина О.В. \\ доктор экономических наук, старший научный сотрудник \\ отдел рыночных механизмов и структур \\ Институт проблем рынка и экономико-экологических исследований НАН Украины \\ Французский бульвар, 29, г. Одесса, Украина, 65044 \\ E-mail: ksenkych@gmail.com
}

\title{
ВОСПРОИЗВОДСТВЕННЫЙ МЕТОДИЧЕСКИЙ ПОДХОД К ОЦЕНКЕ ЭФФЕКТИВНОСТИ ИНТЕГРИРОВАННЫХ ТОВАРНЫХ РЫНКОВ
}

В статье раскрыто природу секторной добавленной стоимости как внутренний вклад определенного сектора в формирование стоимости товара (услуги) на интегрированном рынке. Разработана теория кругооборота секторной добавленной стоимости в мезосистеме, которая выделяет два этапа ее движения (процессы формирования и процессы использования), межсекторное перераспределение (миграцию) стоимости, внутренние и внешние противоречия экономических интересов участников процесса воспроизводства (субъектов рынка, работников и государства). Данная теория сформировала теоретический базис для воспроизводственного методического подхода к оценке эффективности функционирования интегрированных товарных рынков. 
Главной целью методического подхода является многоуровневая оценка эффективности формирования и использования добавленной стоимости по этапам ее кругооборота в секторном и рыночной измерении как методический базис принятия управленческих решений для сбалансирован ного развития интегрированных товарных рынков, формирования механизма государственного управления добавленной стоимостью в стратегических рынках страны. Множество принципов оценки эффективности рынков формируют: (1) приоритетность экономических интересов государства как носителя интересов общества; (2) системность и комплексность; (3) адекватность и гибкость; (4) объективность и точность; (5) действенность; (6) целенаправленность; (7) научность.

Воспроизводственный методический подход включает три этапа: (1) идентификация релевантного рынка; (2) оценка его эффективности функционирования с помощью множества показателей; (3) диагностика релевантного рынка, анализ межсекторных балансов показателей эффеекивности, прогнозные сценарии развития рынка. Ядром методического подхода является трехуровневая система показателей, разработанная автором: (1) оценка эффективности формирования добавленной стоимости в мезосистеме с акцентом на ресурсную структуру стоимости; (2) оценка производительности фракторов производства; (3) оценка эффективности фрискального и воспроизводственного использования добавленной стоимости в интегрированном рынке. Практическая значимость методического подхода определяется возможностью его использования в аналитической и управленческой деятельности субъектов рынка, их объединений, государственных и региональных органов власти.

Ключевые слова: добавленная стоимость, мезосистема, эффективность интегрированных товарных рынков, кругооборот секторной добавленной стоимости, управление стоимостью.

\author{
Nikishina 0. \\ Doctor of Economics, Senior Researcher \\ Department of market mechanisms and structures \\ Institute of market problems and economic \& ecological research \\ of National Academy of Sciences of Ukraine \\ Frantsuzskiy boulevard, 29, Odessa, Ukraine, 65044 \\ E-mail: ksenkych@gmail.com
}

\title{
REPRODUCTION METHODICAL APPROACH TO EVALUATION OF THE EFFECTIVENESS OF INTEGRATED COMMODITY MARKETS
}

The article reveals the nature of sector added value as internal contribution of a certain sector in formation of value of goods (service) at the integrated market. The theory of circulation of sector added value in the mezosystem, which allocates two stages of its movement (the processes of formation and processes of use), inter-sector reallocation (migration) of value, internal and external contradictions of economic interests of the participants in the reproduction process (market entities, employees and the state). This theory formed the theoretical basis for reproduction methodical approach to evaluation the effectiveness of functioning of the integrated commodity markets.

The main purpose of the methodical approach is a multilevel evaluation of efficiency of formation and use of added value by the stages of its circulation in sector and market dimension as the methodical basis of managerial decision making for balanced sustainable development of integrated commodity markets, formation of mechanism of the state management by added value in the strategic markets of the country. Plenty of principles for evaluation the effectiveness of the markets form: (1) priority of economic interests of the state as a bearer of public interests; (2) systematic character and complexity; (3) adequacy and flexibility; (4) objectivity and accuracy; (5) efficiency; (6) purposefulness; (7) scientific character.

The reproduction methodical approach involves three steps: (1) identification of a relevant market; (2) evaluation of its effectiveness of functioning by using the set of indicators; (3) diagnostics of a relevant market, the analysis of inter-sector balances of efficiency indices, forecast scenarios of a market development. The core of the methodical approach is a three-level system of indicators, developed by the author: (1) evaluation of effectiveness of the formation of added value in a mezosystem with an emphasis on a resource structure of the value; (2) performance evaluation of the production factors; (3) evaluation of effectiveness of fiscal and reproduction use of added value in the integrated market. The practical significance of the methodical approach is determined by the possibility of its use in the analytical and management activity of entities of the market, their associations, state and regional authorities.

Keywords: added value, mezosystem, effectiveness of integrated commodity markets, circulation of sector added value, management of the value. 


\section{References}

1. Avdasheva, S. B. , et al. "Modernyzatsyia predpryiatyi v tsepochkakh dobavlennoi stoymosty ." Эkonomycheskyi zhurnal VShЭ, vol. 3, 2005, pp. 361-377.

2. Buluha, R., \& Kokhno, P. (2007). Dobavlennaia stoymost kak tselevoi kryteryi. , Эkonomyst, 10, 68-76.

3. Hridchina , M. V. (2013). Pro dodanu vartist yak pokaznyk rezultativ diialnosti suchasnykh korporatsii . Naukovi pratsi MAUP, 1(36), 126-129.

4. Ivanenko , V. O. (2012). Dodana vartist yak ob'iekt analizu statystychnoi zvitnosti promyslovykh pidpryiemstv z vyrobnytstva produktsii . Problemy teorii ta metodolohii bukhhalterskoho obliku, kontroliu i analizu, 1(22), 122-130.

5. Izmailova, K. V. (2001). Finansovyi analiz . K.: MAUP.

6. Kovalenko , O. V. (2015). Dodana vartist u konteksti natsionalnoi prodovolchoi bezpeky. Ekonomika ta derzhava, 4, 98-102.

7. Lysyuk,, V. M. (2014). Organization of the commodity market: theory and practice: monograph. Saarbrucken, Deutsehland: LAP LAMBERT Academic Publishing.

8. Savytskaia, H. V. (2002). Analyz khoziaistvennoi deiatelnosty predpryiatyia . Mynsk: OOO «Novoe znanye».

9. Synk , D. S. (1989). Upravlenye proyzvodytelnostiu: planyrovanye, yzmerenye y otsenka, kontrol y povыshenye. M.: Prohress. 23022.html.

10. Contemporary Encyclopedia. Retrieved 2017, from http://enc-dic.com/word/d/Dobavlennaya-stoimost-

11. Economic dictionary. Retrieved 2017, from Retrieved from mirslovarei.com/ content_eco/.

12. Nikishyna, O. V. (2014). Metodychni zasady kryterialnoi otsinky vidtvoriuvalnykh protsesiv na intehrovanomu zernovomu rynku Ukrainy . Ekonomika: realii chasu, 2(12), 139-149. Retrieved from http://economics.opu.ua/files/archive/2014/No2/139-149.pdf.

13. Nikishyna, O. V. (2014). Criterion of Value Added in Assessing Efficiency of Integrated Markets Grain and Products his Processing in Ukraine. Nauka i Studia, 20(130), 52-57.

14. Nikishyna, O. V. (2017). Metodychnyi pidkhid do otsinky efektyvnosti sub'iektiv intehrovanoho tovarnoho rynku . Formuvannia potentsialu ekonomichnoho rozvytku promyslovykh pidpryiemstv: III mizhn. nauk.-prakt. internet-konf., 27-28 kvitnia 2017 r.: tezy dopov, 66-67. Retrieved from http://economics.opu.ua/files/science/form_ek_rozv/2017/66.pdf

15. Ekonomichna prohrama dlia Ukrainy.Nimetska konsultatyvna hrupa z pytan ekonomichnykh reform pry Uriadi Ukrainy. (2004). K: In-t ekon. doslidzh. ta polit. konsultatsii.

16. Nikishyna, , O. V. (2017). Measures for increase efficiency Ukrainian market of bread and bakery products. . Actual problems of economics: theory and practice: VII International scientific conference, Jun 3 2017: theses report. Vinnitsa: LLC “Nilan-Ltd”, 25-30.

Received 1 June 2017

Approved 14 June 2017

Available in Internet 30.09.2017 